\title{
The metamorphosis of Lewis's dual economy model
}

\author{
Dipak Ghosh
}

\begin{abstract}
This paper argues that Arthur Lewis originally presented the problem of economic development in terms of an open system, in the sense that it focused on a number of possible pitfalls and socio-economic constraints in the process of capital accumulation and industrialization in a labour-surplus economy. In the hands of the neoclassical economists, who were predominantly interested in achieving deterministic equilibrium results by introducing strict assumptions, the theoretical system later became closed - something Lewis never intended.
\end{abstract}

Keywords: economic development, dual economy models, development methodology, marketable surplus, open system, closed system

JEL Classifications: B41, O10, O17, O29

\section{INTRODUCTION}

Lewis's (1954) seminal article 'Economic development with unlimited supplies of labour' 'is widely regarded as the single most influential contribution to the establishment of development economics as an academic discipline' (Kirkpatrick and Barrientos 2004: 679). However, as is common in the case of seminal contributions, what Lewis actually tried to say has gone through a number of transformations, in the hands of other researchers, starting from the definition of a dual economy. These changes perhaps tell us more about the development of economics rather than the process of economic development. When Lewis presented an analysis of the process of economic development for a specific group of economies with 'surplus labour', his objective was not to present a deterministic theoretical model, unlike the plethora of neoclassical models of the dual economy that followed in its wake. What may be described as Lewis's open theoretical system metamorphosed into a closed system in the hands of neoclassical contributors.

In this article, we make an attempt to investigate this metamorphosis. Lewis (1954) looked at the problem of economic development from the context of both a closed and an open economy (in terms of relations with 
other economies). But we will carry out our investigation entirely in the context of a closed economy, since the neoclassical models which we will refer to all deal with the problem in that context. We must also make it clear at this point that this is not a survey of dual economy models. For this readers are referred to Worrell (1980) and Kanbur and McIntosh (1988). The neoclassical models we will refer to here are due to Dixit, Fei, Jorgension and Ranis. However, our main argument about the neoclassical metamorphosis applies equally to other neoclassical contributors e.g. Kelley et al. (1972).

In what follows, we present a short discussion of the early days of the subdiscipline of development economics. Then in section 3 we present a sketch of the Lewisian model and the neoclassical presentations of models of the dual economy. In section 4 we discuss Lewis's methodology and system; the terms of trade between the food-producing, subsistence sector and the capitalist sector when the sector providing the marketable surplus of food grains is predominantly peasant-dominated; the neoclassical treatment of the terms-of-trade problem; and finally a closer look at the nature and implications of the neoclassical approach for Lewis's methodology.

\section{THE BIRTH OF DEVELOPMENT ECONOMICS}

Development economics, as a sub-discipline of economics, was born after the Second World War. In the words of Galbraith (1989: 258-9) this period witnessed 'for the first time a lively interest in the nature of the development process in the countries newly released from colonial rule. Economic development became a separate field of research and study'. Following the start of the process of decolonization, '[i]t was felt that the studies and courses of colonial economics which were designed for people working for, or hoping to enter, the colonial services will no longer suffice' (Meier 1994: 174).

The neoclassical orthodoxy, which was firmly in place during the period which witnessed the end of the Second World War and the start of the process of decolonization, was defined for the economics profession by Lionel Robbins's The Nature and Significance of Economic Science (1932) (Deane 1978: ch. 10). It is therefore perhaps not surprising that the majority of economists working in the area of economic development utilized the analytical tools of neoclassical economics for the problem at hand. Be that as it may, Robbins himself, following in the footsteps of John Neville Keynes (1930), 'virtually excluded' theory of economic development 'because it must involve assumptions that are relative to time and place and/or must take account of changes in social and political organisations' (Deane 1978: 147).

Even during these early days of development economics, some observers could not fail to notice that the new sub-discipline was 'one that suffered 
significantly from an inclination to urge on countries in earlier agrarian modes the policies and associate administrative apparatus appropriate to advanced stages of industrial development' (Galbraith 1989: 259). The same author also observed that, in the US, 'the considerable number of students from the poor countries under one scholarship arrangement or another [who came] to study economics, ... were now studying the sophisticated models applicable, if at all, only to the United States and other advanced countries' (Galbraith 1979: 30).

From these early days, when economists turned their attention to the problem of economic development, only a very few, like Lewis (and also Myint 1968), consciously went back to classical economists for inspiration. 'But the majority of such economists tried to combine neoclassical and classical economies in an eclectic synthesis, and most refused to see existing societies as riven into classes and driven by their conflicts' (Bagchi 1982: 5). With one exception, the neoclassical literature on development economics does not seem to reflect much evidence of impact of Robbins's misgivings about the inapplicability of the neoclassical orthodoxy to problems of economic development.

The one exception is the contribution of a Dutch economist, J.H. Boeke. Boeke's views on the problems of developing economies were formed when he was employed as a Netherlands East Indies civil servant and subsequently as a professor of Eastern economies at Leiden University. Though the views expressed in his monograph, Economics and Economic Policy of Dual Societies (1953), were predominantly based on his experience in Indonesia, he maintained that his theory of 'social dualism' could be applied to analysing other post-colonial economies as well. According to Boeke, 'social dualism is the clashing of an imported social system, usually high capitalism, against an indigenous one' (Boeke 1953: 4). This dualism according to him is a form of disintegration brought about by the appearance of capitalism in pre-capitalistic societies. To Boeke, dualism has nothing to do with colonialism, but arises from a clash between the East and the West. One of the main characteristics of dualistic societies which he emphasized was that, while Eastern societies have 'limited needs', Western societies in sharp contrast have 'unlimited needs'. For this reason 'any one expecting western reactions (in a dualistic society) will meet with frequent surprises' (ibid.: 40). Boeke argued that Eastern economies, in contrast to Western ones, are characterized by backward-sloping supply curves of effort and risk taking (Higgins 1968: 228). In his view, a closely related feature of Eastern societies is the almost complete absence of profit seeking.

The policy implications of Boeke's analysis of economic problems in postcolonial economies was that 'the kindest thing the Western world can do for underdeveloped areas is to leave them alone; any effort to develop them along Western lines can only hasten their retrogression and decay' (Higgins 1968: 229). One can look at the policy implication that Boeke arrived at as 
one closer to Robbins's view regarding the inapplicability of the tools of the orthodox neoclassical economics to analyse the problem of economic development. Boeke could not see how economic models developed with reference to 'rational' optimizing agents could be applied to analysing economies populated by 'irrational' satisficing agents.

In spite of these reservations regarding poor peoples' ability to develop, development economics as a sub-discipline of economics 'saw a remarkable outpouring of fundamental ideas and models which were to dominate the new field and to generate controversies that contributed much to its liveliness' (Hirschman 1982: 372). One of a list of possible reasons behind this growth of interest mentioned by Galbraith (1979) is that some economists may have thought that, were the tremendous economic success in the industrial countries during the post-war period to continue, the developed industrial world would not have any economic problems left to tackle. Given Keynes's warning to the economics profession as far back as 1930 that 'the economic problem is not - if we look into the future - the permanent problem of the human race' (Keynes 1972: 326, emphasis in original), some economists started to look for other problems to solve. According to Galbraith (1979: 32-3) '[t]o be involved with the poor countries provided the scholars with a foothold in a field of study that would assuredly expand and endure'.

\section{DUAL ECONOMY MODELS}

\subsection{Lewis's original approach}

As noted above, Lewis's essay 'is written in the classical tradition, making the classical assumption and asking the classical question' (Lewis 1954: 139), i.e. (i) the classical tradition from Smith to Marx; (ii) the classical assumption of availability of 'unlimited supply of labour' at 'subsistence wages'; (iii) the classical question of how, in such an economy, 'production grows through time'. The answer to this classical question, according to Lewis, is capital accumulation which was linked to the distribution of income.

Lewis's reading of Keynes's General Theory was that, during a period of recession, labour as well as land and capital are in short supply only over the short period. This was unlike the problem he was dealing with, where the supply of labour is unlimited, while that of the capital and land (natural resources) is in short supply. The three economies which Lewis named as examples of countries containing surplus labour were Egypt, India and Jamaica, where 'population is so large relatively to capital and natural resources, that there are large sectors of the economy where marginal productivity of labour is negligible, zero or even negative' (Lewis 1954: 141). 
It is important to remember that Lewis (1954: 142) emphasized that the phenomenon is not by any means confined to 'the countryside', as well as that ' $[\mathrm{w}]$ hether marginal productivity is zero or negligible is not, however, of fundamental importance' to his analysis. What is important is that the supply of labour is 'unlimited' at a wage at the 'subsistence' level in the sense that supply at this price exceeds demand. 'In this situation new industries can be created or old industries expanded without limit at the existing wage; or to put it more exactly, shortage of labour is no limit to the creation of new sources of employment'. In this context Lewis wanted readers to cease asking the question 'whether the marginal productivity of labour is negligible' and ask instead the question 'from what sectors the additional labour be available if new industries were created offering employment at subsistence wages' (Lewis 1954: 142).

The two sectors in Lewis (1954) are the 'capitalist sector' and the 'subsistence sector'. The capitalist sector is defined as 'that part of the economy which uses reproducible capital and pays capitalists for the use thereof'. The subsistence sector 'is all that part of the economy which is not using reproducible capital' (Lewis 1954: 147). Per capita output is lower in the subsistence sector than in the capitalist sector, 'because it is not fructified by capital (this is why it is called "unproductive")'. With availability of additional capital, more workers can be drawn from the subsistence sector to the capitalist sector and the per capita output of these workers rises. Note that neither of these two sectors was exclusively identified with agriculture or industry. As Lewis points out, one may very well find 'a few highly capitalized plantations, surrounded by a sea of peasants'.

The process of economic development then depends on the transfer of surplus labour from the subsistence to the capitalist sector. The size of the initial absorption of labour in the capitalist sector depends on available capital. As there is an unlimited supply of labour at a subsistence (or slightly above subsistence) wage rate, the transfer of labour helps capital to accumulate in the hands of the capitalists. During the next period the additional capital accumulated helps more labour to move from the subsistence to the capitalist sector, which gives rise to further capital accumulation and transfer of labour. This process continues till the supply of surplus labour at the subsistence wage is exhausted. In Lewis's words,

(t)he key to the process is the use which is made of the capital surplus. In so far as this is reinvested in creating new capital, the capitalist sector expands, taking more people into capitalist employment out of the subsistence sector. The surplus is then larger still, capital formation is still greater, until the labour surplus disappears.

(Lewis 1954: 152, emphasis added)

Lewis emphasized that 'this subsistence income remains constant throughout the expansion, since by definition labour can be yielded up to the 
expanding capitalist sector without reducing subsistence output' (Lewis 1954: 157-8).

We have presented above the central character of Lewis's model of economic development in a dual economy with surplus labour. However, Lewis took great pains to draw attention to the possibility that this process may stop even before capital accumulation has caught up with population, so that there is no longer surplus labour in the subsistence sector. We will postpone our discussion of the possible reasons Lewis considered for this, and its implications, till section 4.2 below. However, what we will see in the following section is that the neoclassical dual-economy models concentrated on what can perhaps be described as the 'ideal' model of the process of labour transfer, capital accumulation and economic development Lewis started with when 'setting the scene'.

\subsection{The neoclassical models}

In their survey article on dual economy models, Kanbur and McIntosh (1988: 83) consider the survey article by Dixit (1973) as a kind of landmark in earlier research on dual economies. This article, a frequently referenced starting point for most articles on dual economy models, is essentially a synthesis of the models by Fei, Ranis and Jorgenson. We will refer to Dixit's contributions in section 4.3 below.

In the hands of Ranis and Fei (1961) and Fei and Ranis (1964, 1966), the central feature of dualism implied:

the coexistence of a large agricultural sector with an active and dynamic industrial sector. Industry uses capital, and both sectors undergo continuous technological change as they 'interact' during the growth process. The dualistic economy strives to adjust the historical preponderance of agriculture by gradually shifting its centre of gravity toward industry through factor reallocation. Its inherent condition is thus one of change, and its vision of the future is the ultimate graduation into economic maturity.

(Fei and Ranis 1966: 4, emphasis added)

We can see that Lewis's capitalist and subsistence sectors have changed to the industrial and agricultural sectors.

The analysis of the dual economy by these two authors was 'to make a contribution towards the theory of growth by rigorously analyzing the transition process through which an underdeveloped economy hopes to move from a condition of stagnation to one of self-sustaining growth' (Ranis and Fei 1961: 533). After acknowledging that their paper had drawn heavily upon the work of Lewis $(1954,1958)$ they note that Lewis 'presents a two-sector model and investigates the expansion of the capitalist or 
industrial sector as it is nourished by supplies of cheap labour from the subsistence or agricultural sector' (Ranis and Fei 1961: 533-4).

Their methodological approach is reflected in the following observation:

Lewis, however, has failed to present a satisfactory analysis of the subsistence or agricultural sector. It seems clear that this sector must also grow if the mechanism he describes is not to grind to a premature halt. Pursuit of this notion of a required balance in growth then leads us to a logically consistent definition of the end of the take-off process.

(Ranis and Fei 1961: 534)

In Jorgenson $(1961,1966,1967)$ the two sectors are 'the advanced or modern sector' - which are called the industrial or manufacturing sector and 'the backward or traditional sector' - which was denoted as agriculture. According to Jorgenson,

Lewis postulates that the fundamental characteristic of certain less developed economies is the existence of disguised unemployment. Lewis's analysis of the role of the unemployed in the determination of wages during economic development is strictly analogous to that of Marx.

(Jorgenson 1967: 289, emphasis added)

But Lewis's concept of surplus labour has very little to do with the concept of disguised unemployment. Joan Robinson (1936) first introduced the term 'disguised unemployment' to describe workers in developed countries who accepted less productive hand-to-mouth occupations as a result of being laid off due to lack of effective demand. As we have already seen, Lewis (1954) attempted to distinguish between the concept of surplus labour in dual economies and unemployed labour in the world of the General Theory. This was for the reason that, in the economy Keynes described, 'not only that labour is unlimited in supply, but also, and more fundamentally, that land and capital are unlimited in supply - more fundamentally both in the short run sense' (Lewis 1954: 140). Nor did Lewis find the concept of unemployment in the sense of Marx's reserve army of labour appropriate for the problem he was dealing with. He rejected Marx's argument on empirical grounds for, according to Lewis, 'the effect of capital accumulation in the past has been to reduce the size of the reserve army and not to increase it' (Lewis 1954: 145).

Looking closely, the dual economy models proposed by Jorgenson deal with a somewhat different problem from that due to Lewis. According to Jorgenson, in contrast with Lewis's 'classical approach', surplus labour in the subsistence sector and its availability at a constant wage rate cease to exist in Jorgenson's model. In Jorgenson's

neo-classical approach, labour is never available to the industrial sector without sacrificing agricultural output. From the point of view of the 
industrial sector, the real wage rate rises steadily over time, depending on the rates of technological progress in both sectors and the rate of capital accumulation.

(Jorgenson 1967: 290)

\section{SYSTEMS AND METHODOLOGIES}

\subsection{The development process in Lewis}

Lewis $(1954,1958)$ took great care to discuss different possible scenarios which could affect the process of industrialization (and hence economic development) differently. He was not predisposed to draw up a wellbehaved deterministic system resulting in a single stable equilibrium. In these two papers, Lewis discussed varieties of possible constraints which can negatively affect the process as well as rate of capital accumulation. He cited the following four reasons. First, the rate of growth of capital accumulation being faster than that of population forces the capitalist sector's wage rate to rise above the subsistence rate. Second, the increase in the size of the capitalist sector relative to the subsistence sector may turn the terms of trade against the former and force the capitalist sector to pay workers a higher percentage of their output, in order to keep their real income constant. Third, the subsistence sector itself may become more productive over time. Finally, keeping in mind that the subsistence wage level is determined according to the prevailing convention, the wage rate in the capitalist sector may be forced to rise, even without any changes in the productivity of the capitalist sector, in the event of a change in that convention according to which the subsistence wage level is set (Lewis 1954: 172-3). According to Lewis any one of these four reasons can cause the process of capital accumulation to slow down or even stop.

To understand Lewis's methodology, it is essential to understand his debt to economic history, statistics and sociology as well as the true message of the classicists. Consider Lewis's observation:

[O]ne of the weaknesses of our subject, [is] mainly the widening gap between Economics and Economic History in Development Economics. If our subject is lowering its sights, this may be because the demise of Economic History in economics departments has brought us a generation of economists with no historical background. This is in marked contrast with the development economists of the 1950's, practically all of whom had had some historical training and guided by Gerschenkron and Rostow, looked to history for enlightenment on the process of development. ${ }^{2}$

(Lewis 1984: 7)

Tignor (2004) pointed out that the reading of British economic history led Lewis to identify the two main ingredients behind the industrial revolution 
which could be found in the less developed countries with surplus labour. The first of these came from his readings of J.L. and Barbara Hammond's 1913 monograph on The Village Labourer: A Study in the Government of England before the Reform Bill, which demonstrated that British industrialists benefited from the availability of cheap surplus labour from the agricultural sector. The second ingredient came mainly from his reading of historical statistics on the British economy from the contributions of such economic historians as G.D.H. Cole and T.S. Ashton. This second ingredient was that 'the availability of cheap labor caused industrial profits to soar and enabled business persons to reinvest their profits in business expansion' (Tignor 2004: 699).

When analysing Lewis's methodological approach, Wisman observed that:

Lewis managed to escape practically all of the intellectually debilitating trends since the 1930's while profiting from that which has been so beneficial for the science ... Lewis neither shackled by the ideology of natural law cosmology nor driven toward formalism by the ideology of positivism, has been able to advance economic understanding in a manner relevant to public policy concerns. Joseph Schumpeter characterized the 'scientific' economist as one with a command of history, statistics, 'theory', and economic sociology. If this characterization is correct, then W. Arthur Lewis must be viewed as the consummate 'scientific' economist ... What he possesses in addition to the greater part of today's orthodox economists is a command of history and economic sociology, and practically complete freedom from the ideology of positivism.

(Wisman 1986: 169)

These characteristics are reflected in Lewis's (1984: 8) observation that 'a search for "the" engine of growth must be foredoomed' for the reason that ' $(\mathrm{t})$ here is no one growth theory' and as such he was not looking for this elusive 'single theory'. Lewis's goal was to understand 'the fundamental economic process underlying the transformation of traditional economics into mature industrial economies' (Wisman 1986: 171) along with the possible constraints the socio-economic conditions of such economies may generate.

Why is an understanding of the constraints imposed by the socioeconomic conditions of such importance to Lewis's thinking? The answer can be found in Lewis's observations that:

[t]here remain two categories of cases where the assumptions of market economies may not hold. The first is almost exclusively a phenomenon of poor countries. Here some production and exchange are governed not by desire for income maximization, but by other 'noneconomic' considerations. Thus in some countries living near subsistence level, production 
and exchange are governed by ritual laws, based on kinship and on authority status.

(Lewis 1984: 3; emphasis in original)

[t]he argument for an anthropological approach is not confined to poor countries. The study of economic behavior in rich countries would benefit from more observation (statistical as well as anthropological) rather than more deductive reasoning. Large elements of human behavior - investing, saving, having children, bearing or avoiding risks, setting attainable targets - are not dominated by the calculus of marginal utility, unless utility is given a universalistic and therefore useless meaning.

(Lewis 1984: 4)

\subsection{The marketable surplus problem}

In what follows, we will discuss one of the four reasons which can slow down or even halt the process of capital accumulation which Lewis (1954: 173) found to be 'the most interesting': that of the terms of trade between the capitalist sector and the subsistence sector moving against the former under a situation where the two sectors are producing different products. To be more specific, as Lewis pointed out, under this situation 'the subsistence sector consists of peasants producing food, while the capitalist sector produces everything else' (Lewis 1954: 173, emphasis added). Lewis further elaborates this point thus:

Now if the capitalist sector produces no food, its expansion increases the demand for food, raises the price of food in terms of capitalist products and so reduces profits. This is one of the senses in which industrialisation is dependent upon agricultural improvement; ... if we postulate that the capitalist sector is not producing food, we must either postulate that the subsistence sector is increasing its output, or else conclude that the expansion of the capitalist sector will be brought to an end through adverse terms of trade.

(Lewis 1954: 173)

An understanding of the process of the supply of food from the subsistence sector, the so-called problem of marketable surplus, is crucial for our arguments that follow. (In the literature, the term is usually used to mean marketed surplus of agricultural products.) The significance of the difference between the terms 'marketed surplus' and 'marketable surplus' was first spelled out by Mathur and Ezekiel (1961), who pointed out that, in a non-monetized or partially monetized sector of an economy - a feature of the subsistence sector - where the farmers' demand for cash is limited, farmers retain their savings, when they can afford to save, in kind. For this 
reason, not all marketable surplus, as defined above, is actually marketed. This savings behaviour of the subsistence sector can give rise to the phenomenon of the supply curve of the marketed surplus, after being positively sloped at the beginning, ultimately becoming negatively sloped. In other words, the price elasticity of supply of marketed surplus becomes negative. A backward-bending supply curve of the marketed surplus for food grains can also be explained using the standard tools of demand theory, where the price of food directly affects farmers' income.

The savings behaviour of the farmers, giving rise to the negative price elasticity of supply of food, can also be explained with reference to the nature of risk and uncertainty the farmers in the subsistence sector face. For example, in the case of crop failure during one year, the farmer is compelled to borrow from a landlord or moneylender, to protect his family from starvation. These loans are usually in kind. Since a peasant farmer has very little or no formal collateral, when he is forced to borrow, he may have to offer the lender, as collateral, the small amount of land he owns, a promise of future labour (including that of his wife and children) during the next agricultural season to the lender. For this reason the cost of any crop failure could be destitution for himself as well as his family (Mathur and Ezekiel 1961; Ghosh 1986).

What is the link between the supply of marketed surplus of food and the creation of employment in the capitalist (non-food producing) sector? As Sen (1975: 84-7) argues, the total opportunity for the creation of wage employment in an economy depends on the available supply of 'wage goods', or what Kalecki (1960) calls 'necessities'. Necessities are products the demand for which 'increases because either the wages of the newlyemployed will be higher than their previous consumption, or the income of the peasants who remain in agriculture will increase or both' (Kalecki 1960: 60). An appeal to Engel's law tells us that these wage goods or necessities, for low income groups, are mainly food grains.

Sen (1975: 85) sets out the relationship $\hat{E}=\frac{M}{w}$, where $\hat{E}$ denotes the total opportunity for wage employment, $M$ is the supply of wage goods and $w$ is the real wage rate. From this we can see that, in the event of any reduction of the supply of wage goods - which is the supply of marketed surplus of food at the early stage of economic development - the overall impact on total employment can be negative. ${ }^{3}$

Lewis reiterates the importance of constraints on the supply of wage goods from peasant agriculture as follows:

We know that productivity can increase sharply in peasant agriculture if research is being done in peasant problems, and if an agricultural extension system, and agricultural credit system, roads, water supplies and so on are provided on an adequate basis. We also know, however, that peasant agriculture has a tendency to stagnate in the absence of such 
measures, and also that such measures have been adopted in relatively few countries. If the capitalist sector trades with the peasant sector (e.g. depends on it for food or raw materials and therefore for markets), its continued expansion would be menaced if the peasant sector were stagnant, since this would move the terms of trade against the capitalist sector. In practice, failure of peasant agriculture to increase its productivity has probably been the chief reason holding down the expansion of the industrial sector in most of the under-developed countries of the world.

(Lewis 1958: 22-3)

\subsection{The neoclassical treatment}

Let us consider how Lewis's methodology was viewed by some neoclassical development economists. In their festschrift article in honour of Lewis, Ranis and Fei wrote, ostensibly to congratulate Lewis, that:

Both in the choice of subject matter, and in method of analysis, Arthur Lewis is clearly more comfortable in the company of Classicists. But while it is generally recognized that he deserves major credit for reintroducing us to the Classical tool kit, it is our contention that he deserves even more credit for applying those tools to a really rather different problem, and in a rather different historical and analytical context. We will also conclude that not all of the voluminous literature to which his seminal contribution gave rise has been fundamentally constructive.

(Ranis and Fei 1982: 31-2)

Lewis had accepted the generality of economic analysis for both developed and developing countries, but only up to a simple level:

We are not going to find an unbridgeable gap between Development Economics and the Economics of the Developed, any more than a paediatrician would claim that geriatrics was an unrelated body of knowledge. The overlap between the developing and developed is bound to be great. The more so in economics because the two basic tools, Supply and Demand and the Quantity Theory of Money, will take you a very long way if you just want to understand what is going on. This is why there are so many good untrained economists, and also why some of our most high-powered colleagues perform no better in practical matters than a good undergraduate.

(Lewis 1984: 2)

Neoclassical economists like Fei and Ranis, in spite of the sentiment expressed in the 1982 quotation above, showed some reluctance to accept 
that Lewis's model is based on what, in their reading, the classical economists really meant. For, according to Ranis, in the world of the classicists:

[t]he non-agricultural sector, fed by the capitalist profits, is not really modelled but, except in Smith's (1880) more optimistic view, represents but a temporary deviation from ultimate agricultural transactions, resulting from population growth squeezing out capitalist profits in the absence of reliable technological change.

(Ranis 2004: 713)

It seems that these authors were also of the opinion that Lewis's choice of the classical tool kit was perhaps not appropriate for the problem he was trying to analyse. Since,

when endeavouring to extract the maximum transferable knowledge from the writings of the physiocrats and the classicists, for example, we must be painfully aware that each such formulation is inevitably the product of its own particular historical considerations and circumstances ... Therefore the usefulness of past theories is limited for examining the problems facing us now in the less developed world.

(Fei and Ranis 1966: 3)

It is not that the neoclassical literature on dual economy models does not recognize the fact that, for industrial development, the agricultural sector must develop as well. The differences between these models and Lewis's model is that the neoclassical authors seem to impose conditions, without empirical justification as being more appropriate to modern circumstances, in order to arrive at an equilibrium solution, while Lewis takes great care instead to underline the constraints and pitfalls on the path of capital accumulation. The problems they addressed were indeed different.

In Jorgenson's model, the income elasticity of demand for food by the peasants drops from one to zero when their income reaches a certain level. For this reason, any additional agricultural output generated by farmers through the transfer of labour from the agricultural to the industrial sector will automatically be sold in the market.

Jorgenson recognizes differences between the neoclassical and classical theories' characterization of what he calls the 'backward' or 'traditional' sector. He acknowledges that

[t]he differences between the two approaches also have implications for the behavior of the advanced sector; unfortunately, these implications depend on the actual behavior of the terms of trade between the backward and the advanced sectors. In the neoclassical approach the terms of trade may rise and fall; in the classical approach, they cannot be determined endogenously. Alternative assumptions about the course of 
the terms of trade may be made. Corresponding to each assumption, there is an alternative theory for the behaviour of the advanced sector.

(Jorgenson 1966: 46)

The solution that Jorgenson offers in mitigation of this 'unfortunate' implication of the unpredictable behaviour of the terms of trade is that '[w]e have developed the classical theory in detail only on the assumption that the terms of trade between the backward and advanced sectors remain constant' (ibid.). On the basis of this assumption, he goes on to derive a number of 'well behaved' results for what he calls the 'classical model'.

In Fei and Ranis's models, land is owned not by peasants but by landlords. The peasants only receive their average product as wage payment. The surplus is appropriated by landlords who sell it to the industrial sector. Neither in Jorgenson nor in Fei and Ranis do we encounter any possibilities of a backward-bending supply curve of marketed surplus. Though some neoclassical authors have recognized the possibility that the supply curve of food may not always be positively sloped, their method of solving the 'problem' by assuming it out of existence is familiar although rather 'heroic'.

For example, Dixit (1969: 207-8) found that 'the marketed surplus may be a decreasing function of [price] ... No sensible maximization is possible in this case, however, and it is ruled out locally if we assume local stability of a competitive equilibrium in the food market. I shall in fact rule it out globally by assumption' (emphasis added). Dixit then went on to demonstrate that the relative price between the industrial and agricultural sectors' products 'depends very crucially on the supply and demand functions for food' (Dixit 1969: 216-17). ${ }^{5}$

The treatment of the marketed surplus problem by the neoclassical economists took the form of either ignoring it or assuming it out of existence. It is not difficult to imagine the motivation for such an approach. Given their preoccupation with building a comprehensive system which should incorporate 'sensible' optimization and well-behaved equilibrium, these assumptions are perhaps justified. But it can also be argued that in their search for well-behaved, deterministic models these researchers have found the solution to a problem which Lewis himself never set out to address.

\subsection{The closure of Lewis}

Loasby (2003: 291) observed that, '[a]ny system consists of elements of connections between them ... If every element is connected to every other element, the system (real or conceptual) exists in integral space' and he cites general equilibrium models in economics as an example. For this reason, in the methodology of general equilibrium analysis for which complete connectivity is essential, 'differences in the set of connections can play no 
part in explaining differences between systems. All outcomes are traceable to the elements' (ibid.: 291).

Loasby goes on to suggest that there are different dimensions and degrees of closure of a system:

Completely closed models are obviously limiting cases in terms of degree, but human cognitive powers require a drastic restriction on the number of dimensions in order to secure closure as illustrated by the practice of (neoclassical) economics. Partial closure is necessary for any exploration of openness: we have to close our minds to many possibilities in order to pay attention to a few.

(ibid.: 294)

This is the problem Lionel Robbins encountered (as discussed in section 2) and which prompted him to virtually exclude applying the methodology of neoclassical orthodoxy to the analysis of economic development. Boeke (1953) found it impossible to apply the techniques of a completely connected general equilibrium model developed on the basis of the assumption of rational, and therefore, optimizing agents to analysing the problems of a system populated by 'irrational' non-optimizing agents and decided that such economic systems should be left to their own devices.

The neoclassical literature on dual economy models seems to believe that the lack of complete closure of Lewis's theoretical system, from the perspective of neoclassical general equilibrium models, is due to some type of error or ignorance. For example, Jagdish Bhagwati, in an article written in appreciation of Lewis's contribution on development economics wrote that:

[a]t the very outset, however, it should be stressed that the modelling by Lewis is not exactly in the manner of a modern theoretical piece. It is more in the nature of 'grand design' where relationships are sketched with a broad brush, with a number of important ideas woven in at different places, and models of the narrow type lie within easy reach of the serious theorists.

(Bhagwati 1982: 22, emphasis in original)

It would be interesting to speculate who these 'serious theorists' are meant to be. Be that as it may, this quotation can be read as an acknowledgement by one prominent neoclassical economist of the limitation of application of the tools of neoclassical general equilibrium models to analysis of a system which is only partially closed in the sense of Loasby (2003).

The objection of neoclassical development economists to Lewis's methodology is neatly summarized in the argument put forward by one prominent development economist - Gustav Ranis. He observed that:

[t]he most serious objection to the Lewis model, of course, is that contemporary development economists, working inside the neoclassical 
paradigm, cannot accept the notion of an exogenous unskilled agricultural real wage instead of one that is determined endogenously by the interaction of demand and supply. When they do accept the notion of institutional interventions, it is not a wage set by bargaining but one having to do with insurance over either space or time. This is the crux of the contemporary critique of the Lewis model, i.e. the rejection of an exogenous bargaining wage or consumption share, exceeding the marginal product of labor at any point in time.

(Ranis 2004: 717-18)

And what is the reason behind this rejection? The author continues:

Unfortunately, there is no acceptable model which yields a uniquely determined bargaining wage ... In the absence of a neat theory to determine the level of bargaining wage which may hold for some decades, the Lewis model has been consistently praised, but also increasingly rejected.

(ibid.: 718)

Let us look at Lewis's contributions on the dual economy in the light of the observation that, 'incompleteness is not only a source of problems; it opens up our systems of thought. Whereas there is only one way in which a system can be completely connected, there are many sets of partial connections and, therefore, many possible closures that might be tried' (Loasby 2003: 293). Lewis's list of a number of possible scenarios alerts policymakers to the existence of the many possible closures for models of economic development in a dual economy.

To use the language of Chick and Dow (2005), in Lewis's scenario the structure of the economy and agency (in the sector supplying wage goods) are interdependent and there is imperfect knowledge of the relations between variables (including the sense that the nature of the sector supplying wage goods differs from one economy to another). Also the relationships between such variables as price level and supply of wage goods are not stable (as these are liable to change with the changes in the nature of the sector supplying wage goods). (See sufficient conditions ii and viii for open systems in their Table 1.)

In fact the process of economic growth and development by definition involves changes in socio-economic structure. The system Lewis had in his mind is clearly an over-determined one. In dealing with systems like this, policymakers do not have the luxury to leave the running of the whole economic system under the control of an autopilot. With the passage of time, as the structure of an economy changes, the nature of and constraints on economic development also change. Lewis referred to a number of these constraints, originating from the particular nature of a developing country at any given period of time. ${ }^{6}$ 
As Lewis (1979: 211) puts it, '[t]he dual economy model comes in a wide range of specifications, since each writer is free to make his own assumptions'. However, the neoclassical dual economy models, discussed above, seem to be motivated by the desire to weed out what were seen as 'mistakes' in Lewis's original formulation. For example, Ranis and Fei's (1961) desire was to correct Lewis's failure to provide a 'satisfactory' analysis of the subsistence sector. Jorgenson (1966) assumes that the terms of trade between the two sectors remain constant and Dixit (1969) just assumes away the possibility of the existence of a backward-bending supply curve of the marketable surplus of wage goods.

In their urge to build a 'neat theory' of development of a dual economy by correcting perceived shortcomings in Lewis's original model, what these neoclassical authors of dual economy models seem to have failed to realize is that, in the final analysis, they have replaced what was an open system in Lewis with a closed system. The neoclassical treatment of Lewis's model is not an isolated example of the transformation of an open theoretical economic system into a closed one by the practitioners of the neoclassical orthodoxy. Chick (1996) has illustrated how the economics of Keynes has suffered, and continue to be suffering, from the same fate.

\section{CONCLUSIONS}

It takes time for an economy to develop and for the underlying economic and social structures and institutions to change. As we have seen above (in section 4.1), Lewis never subscribed to the idea that there is 'one growth theory' and as such, he did not want to build one, and close the system completely and permanently in the sense of Loasby (2003) discussed above. All models need closure. However, in Lewis the temporary closure of the system for modelling purposes depends upon the structure and institutions at a given point in time. With the changes and evolution of institutions and structure, the nature of the problem changes, calling for a different manner of closure of the system to help policymaking.

In this paper we have considered one possible scenario in Lewis (1954), that of the supply of wage goods in a peasant-dominated subsistence sector. Since the nature of uncertainty in such a sector is completely different from that of a monetized and commercialized sector, the behaviour of the nonprofit maximizing agents there can adversely affect the creation of employment, and hence the mobilization of surplus labour in the capitalist sector (Ghosh 1986, 2002). For this reason the path of industrialization is not smooth and trouble-free, or susceptible to analysis using the tools of equilibrium economics. One cannot generalize. The economic, social and sociological characters of different economies, both developed and developing, are not identical and in the area of policymaking one size does 
not fit all. The process of economic development takes place over historical time, and historical time, as we know, is irreversible.

Before we finally conclude, we draw attention to what perhaps could be described as almost the 'inability' of the neoclassical development economists to comprehend the open system nature of Lewis's contribution or, in other words, the methodological differences between the two approaches. For example, Findlay (1980: 67-8) is of the opinion that the relationship between the Lewis and Neoclassical approaches is one of complementarity in accounting for the characteristic feature of "modern economic growth", He further points out that "[p]art of the criticism (of Lewis) arises from the view that his model attempts to make the real wage in the "capitalist" sector endogenous, by treating it as determined explicitly as some function of the alternative earnings in the rural sector' (Findlay 1980: 68). But what is endogenous depends on the nature of closure employed in the relevant theoretical system. As we have seen above, the reasons why neoclassical economists found Lewis's contribution unsatisfactory could be found in such observations as that Lewis's model is "not a modern theoretical piece'; 'no sensible maximization' is possible when the supply curve of wage goods can be backward-bending; in the classical system of Lewis the terms of trade between the two sectors 'cannot be endogenously determined'; or that Lewis failed to provide a 'satisfactory' theory of the subsistence sector. Such unwillingness to take account of difference in methodological approach tells volumes about the different, and perhaps even compartmentalized, worlds we economists live in.

Dipak Ghosh

University of Stirling

dipak.ghosh@stir.ac.uk

\section{NOTES}

1 Other than such cultural dualism, tropical soil, climate, natural resources or the so-called environmental dualism have also been blamed for lack of development (Higgins 1968: ch. 11). The sentiments among the development economists and policymakers in the early post-war period have been neatly summarized by Lewis in his Nobel Lecture - 'In 1950(s) these people were sceptical of the capacity of LDCs to grow rapidly because of inappropriate attitudes, institutions or climates. The sun was too hot for hard work, or the people too spendthrift, the government too corrupt, the fertility rate too high, the religion too other worldly, and so on' (Lewis 1992).

2 Examples of the works by the two authors Lewis mentioned can be found in Gerschenkron (1966a, 1966b) and Rostow (1948, 1960).

3 In the case of Keynesian unemployment, any expansion of employment opportunity by generating additional effective demand would automatically lead to an increase in the supply of appropriate wage goods for an 
industrialized economy. The role of the supply of marketed surplus in capital accumulation and industrialization is well documented in the case of early years of economic development of Russia. In 1925-6 the marketed surplus of food failed to recover to its pre-war level even though both the cultivated area for food grain as well as the gross harvest recovered to their pre-war level. Stalin reasoned that the root of the reduction of the marketed surplus problem could be found in the nature of agrarian revolution of 1917. After 1917 distribution of land became more egalitarian and by 1928 poor and middle peasants accounted for 85 per cent of grain production compared to 1.7 per cent by the state and collective firms and 13 per cent by the kulaks. As Dobb (1966: 214) writes, '(t)he village was eating more of what it grew and selling less, because it was more egalitarian than formerly' (see the table quoted by Stalin in Dobb 1966: 217). In his two Economic Notes, Preobrazhensky (1925, 1926), while analysing the causes of the so-called 'goods famine', referred to the problem of marketed surplus of grain. In the first note, he pointed out that the reduction of tax liabilities of the peasants as well as some reduction in the usurious interest paid to the kulaks following the revolution, released a considerable proportion of rural commodity output from forced sales. This, he observed, increased the peasants' consumption of food grains.

4 See the table compiled by the Central Statistical Department of Russia quoted by Stalin, presented in Dobb (1966: 217).

5 One structuralist, Taylor (1979), also is aware of the possibility that the price elasticity of supply of marketable surplus can be negative but then goes on to say, ' $[\mathrm{h}]$ owever, assume for the sake of discussion that the elasticity marketed surplus ... with respect to price is positive ... Then it is reasonable to ask how prices ought to be manipulated to make crops flow towards the city' (Taylor 1979: 173).

6 Joan Robinson (1961: 360-1), in discussing the nature and stability problem in Roy Harrod's model of economic growth, observed that one way to deal with a system which is clearly over-determined and hence open, ' $\ldots$ is to give up the idea of equilibrium and exhibit an economy blundering on from one situation to another (as happens in the history of the world we live in) following no simple predictable path'.

\section{REFERENCES}

Bagchi, A. (1982) The Political Economy of Development, Cambridge: Cambridge University Press.

Bhagwati, J. N. (1982) 'W. Arthur Lewis: an appreciation', in M. Gersovitz, C. F. Diaz-Alezandro, G. Ranis and M. R. Rosenzweig (eds) The Theory and Experience of Economic Development: Essays in Honour of Sir W. Arthur Lewis, London: Allen \& Unwin, pp. 15-27.

Boeke, J. H. (1953) Economics and Economic Policy of Dual Societies, As Exemplified by Indonesia, New York: Institute of Pacific Relations.

Chick, V. (1996) 'Equilibrium and determination in open systems: the case of The General Theory', History of Economics Review 25: 184-8.

Chick, V. and Dow, S. (2005) 'The meaning of open systems', Journal of Economic Methodology 12: 363-81.

Deane, P. (1978) The Evolution of Economic Ideas, Cambridge: Cambridge University Press.

Dixit, A. K. (1969) 'Marketable surplus and dual development', Journal of Economic Theory 1: 203-19. 
Dixit, A. K. (1973) 'Models of dual economies', in J. A. Mirrlees and N. H. Stern (eds) Models of Economic Growth, New York: John Wiley \& Sons, pp. 325-7.

Dobb, M. (1966) Soviet Economic Development since 1917, London: Routledge \& Kegan Paul Ltd.

Fei, J. C. H. and Ranis, G. (1964) Development of the Labour Surplus Economy, Illinois: Irwin.

Fei, J. C. H. and Ranis, G. (1966) 'Agrarianism, dualism and economic development', in I. Adelman and E. Thorbeck (eds) Theory and Design of Economic Development, Baltimore: Johns Hopkins Press, pp. 3-44.

Findlay, R. (1980) 'W. Arthur Lewis' contribution to economics', Scandinavian Journal of Economics 82: 62-79.

Galbraith, J. K. (1979) The Nature of Mass Poverty, Middlesex: Penguin.

Galbraith, J. K. (1989) A History of Economics: The Past as the Present, London: Penguin.

Gerschenkron, A. (1966a) Economic Backwardness in Historical Perspective: A Book of Essays, Cambridge, MA: Harvard University Press.

Gerschenkron, A. (1966b) Bread and Democracy in Germany, New York: Howard Fertig.

Ghosh, D. (1986) 'Monetary dualism in developing economies', Économies et Sociétés 20: 19-30.

Ghosh, D. (2002) 'Savings behaviour of the traditional sector and employment generation in a dual economy', Savings and Development 26: 381-94.

Hammond, J. L. and Hammond, R. (1913) The Village Labourer, 1760-1832: A Study in the Government of England before the Reform Bill, London: Longmans, Green.

Higgins, B. (1968) Economic Development: Problems, Principles and Policies (revised edition), London: Constable.

Hirschman, A. O. (1982) 'The rise and fall of development economics', in M. Gersovitz, C. F. Diaz-Alezandro, G. Ranis and M. R. Rosenzweig (eds) The Theory and Experience of Economic Development: Essays in Honour of Sir W. Arthur Lewis, London: Allen \& Unwin, pp. 372-90.

Jorgenson, D. W. (1961) 'The development of a dual economy', Economic Journal 61: 309-34.

Jorgenson, D. W. (1966) 'Testing alternative theories of the development of a dual economy', in I. Adelman and E. Thorbeck (eds) Theory and Design of Economic Development, Baltimore: Johns Hopkins Press, pp. 45-60.

Jorgenson, D. W. (1967) 'Surplus agricultural labour and the development of a dual economy', Oxford Economic Papers 19: 288-312.

Kalecki, M. (1960) 'Unemployment in underdeveloped countries', Indian Journal of Labour Economics 3: 59-61, reprinted in Jerzy Osiatynski (ed.) Collected Works of Michael Kalecki, Vol.5: Developing Economies, 1993, Oxford: Clarendon Press.

Kanbur, S. M. R. and McIntosh, J. P. (1988) 'Dual economy models: retrospect and prospect', Bulletin of Economic Research 40: 83-113.

Kelley, M. C., Williamson, J. G. and Cheetham, R. J. (1972) Dualistic Economic Development, Chicago: University of Chicago Press.

Keynes, J. M. (1972) 'Economic possibilities for our grandchildren', in The Collected Writings of John Maynard Keynes. Vol. IX: Essays in Persuasion, London: Macmillan.

Keynes, J. N. (1930) The Scope and Methodology of Political Economy, London: LSE (reprint). 
Kirkpatrick, K. and Barrientos, A. (2004) 'The Lewis model after 50 years', Manchester School 72: 679-90.

Lewis, W. A. (1954) 'Economic development with unlimited supplies of labour', Manchester School 22: 139-91.

Lewis, W. A. (1958) 'Unlimited labour: further notes', Manchester School 24: 1-32.

Lewis, W. A. (1979) 'The dual economy revisited', Manchester School 47: 211-29.

Lewis, W. A. (1984) 'The state of development theory', American Economic Review 74: $1-10$.

Lewis, W. A. (1992) 'Slowing down of engine of growth', in A. Lindbek (ed.) Nobel Lectures, Economics 1969-1980, Singapore: World Scientific Publishing Co.

Loasby, B. J. (2003) 'Closed model and open systems', Journal of Economic Methodology 10: 286-306.

Mathur, P. N. and Ezekiel, H. (1961) 'Marketable surplus of food and price fluctuations in a developing economy', Kyklos 14: 396-408.

Meier, G. M. (1994) 'From colonial economics to development economics', in G. M. Meier (ed.) From Classical Economics to Development Economics, Basingstoke: Macmillan, pp. 173-96.

Myint, H. (1968) The Economics of the Developing Countries, London: Hutchinson.

Preobrazhensky, E. A. (1925) 'Economic notes I. on the goods famine', reprinted in D.A. Filtzer (ed.) The Crisis of Soviet Industrialization, 1980, Basingstoke: Macmillan, pp. 33-41.

Preobrazhensky, E. A. (1926) 'Economic notes II', reprinted in D.A. Filtzer (ed.), The Crisis of Soviet Industrialization, 1980, Basingstoke: Macmillan, pp. 42-53.

Ranis, G. (2004) 'Arthur Lewis's contribution to development thinking and policy', Manchester School 72: 712-23.

Ranis, G. and Fei, J. C. H. (1961) 'A theory of economic development', American Economic Review 51: 533-65.

Ranis, G. and Fei, J. C. H. (1982) 'Lewis and the classicists', in M. Gersovitz, C. F. Diaz-Alezandro, G. Ranis and M. R. Rosenzweig (eds) The Theory and Experience of Economic Development: Essays in Honour of Sir W. Arthur Lewis, London: Allen \& Unwin, pp. 31-42.

Robbins, L. (1932) An Essay on the Nature and Significance of Economic Science, 1st edn, London: Macmillan.

Robinson, J. (1936) 'Disguised unemployment', Economic Journal 46: 225-37.

Robinson, J. (1961) 'Equilibrium growth models: a review article', American Economic Review 51: 360-9.

Rostow, W. W. (1948) British Economy of the Nineteenth Century, Oxford: Clarendon Press.

Rostow, W. W. (1960) The Stages of Economic Growth: A Non-Communist Manifesto, Cambridge: Cambridge University Press.

Sen, A. (1975) Employment, Technology and Development, Oxford: Clarendon Press.

Taylor, L. (1979) Macro Planning Models for Use in Developing Countries, New York: McGraw-Hill.

Tignor, R. (2004) 'Unlimited supply of labor', Manchester School 72: 691-711.

Wisman, J. D. (1986) 'The methodology of W. Arthur Lewis's development economics: economics as pedagogy', World Development 90: 165-80.

Worrell, K. (1980) 'The dual economy since Lewis: a survey', Social and Economic Studies 29: 27-51. 